\title{
Fat embolism syndrome after gluteal augmentation with hyaluronic acid: A case report
}

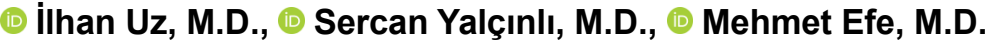

Department of Emergency Medicine, Ege University Faculty of Medicine, Izmir-Turkey

\begin{abstract}
Fat embolism syndrome (FES) occurs classically characterized by the combination of acute respiratory failure, neurologic abnormalities, and a petechial rash. Forty-six-year-old female presented to our emergency department with agitation, altered mental status, and drowsiness. We learned that the patient had received a hyaluronic acid $(\mathrm{HA})$ injection into her buttocks at a beauty center a few hours before her admission. She had no skin findings, but she was hypoxemic. She had lung computed tomography (CT) findings bilateral ground-glass opacities and pleural effusion and had multiple cerebral white lesion on brain magnetic resonance images (MRI). Patients presenting to the emergency department with sudden alteration in mental status should be questioned for recent surgical or invasive aesthetic procedures. Fat embolism syndrome should be considered even if the patient has no petechial rash. Brain MRI and lung CT should be the imaging modality of choice in these patients.
\end{abstract}

Keywords: Emergency medicine; fat embolism syndrome; hyaluronic acid injection.

\section{INTRODUCTION}

Fat embolism (FE) frequently occurs after trauma and during orthopaedic procedures involving manipulation of intramedullary contents. Fat embolism syndrome (FES) is a very rare clinical diagnosis that is based on the classic triad of hypoxemia (pulmonary distress), neurologic abnormalities, and petechial rash. ${ }^{[1]}$ Although part of the "classic triad" of symptoms, a petechial rash occurs in only $20 \%$ to $50 \%$ of the patients. ${ }^{[2,3]}$ Hyaluronic acid (HA) is used as a filler material in cosmetics for soft tissue augmentation in various parts of the body. In this case study, we wanted to share a rare case of FES due to after gluteal augmentation with hyaluronic acid for aesthetic.

\section{CASE REPORT}

Forty-six-year-old female presented to our emergency department with agitation, altered mental status, and drowsiness. We learned that the patient had received a hyaluronic acid (HA) filler injection into her buttocks at a beauty center a few hours before admission. Her past medical history was unremarkable except for peripheral facial paralysis, and the patient did not use any medication regularly. Her relatives stated that she had received $\mathrm{HA}$ injections into her buttocks seven times at the same center previously.

The vital signs of the patient were as follows: Blood pressure: 103/75 mmHg; Heart rate: 65 beats/min; Body temperature: $36^{\circ} \mathrm{C}$; Respiratory rate: 22/minute; Arterial blood gases; Partial pressure of oxygen: $48.6 \mathrm{mmHg}$, Partial pressure of carbon dioxide: $37.3 \mathrm{mmHg}$, A-a gradient=54.8 $\mathrm{mmHg}$ (norm $<20 \mathrm{mmHg}$ ) Oxygen saturation: $90.8 \%$.

On neurological examination, the patient was lethargic with an eye-opening response to verbal and tactile stimuli, and her speech was incomprehensible. Right upper extremity was unresponsive to noxious stimuli. Motor strength was grade $2-3 / 5$ in bilateral lower limbs. Plantar reflexes were extensor bilaterally. Respiratory sounds decreased in the basals. The

Cite this article as: Uz İ, Yalçınlı S, Efe M. Fat embolism syndrome after gluteal augmentation with hyaluronic acid: A case report. Ulus Travma Acil Cerrahi Derg 2020;26:960-962.

Address for correspondence: İlhan Uz, M.D. Ege Üniversitesi Tıp Fakültesi, Acil Tıp Anabilim Dalı, İzmir, Turkey

Tel: +90232 - 3902320 E-mail: ilhan.uz@ege.edu.tr 
remainder of the systemic examination was unremarkable. There were no rashes on the body and no abnormal findings at the injection site. Laboratory analysis, bedside echocardiography, electrocardiogram, brain, and neck contrast-enhanced computerized tomography scans did not reveal any significant findings Thorax computed tomography showed bilateral ground-glass opacities and pleural effusion (see Fig. la). The multiple millimetric hyperintense foci observed in both cerebral hemispheres on the T2-weighted magnetic resonance images (MRI) were thought to be related to fat embolism (see Fig. Ib and c). The enoxaparin $(6,000 \mathrm{lU}(60 \mathrm{mg}) / 0.6$ twice-daily by subcutaneous injection) and methylprednisolone (40 mg/intravenously) were administered to our patient with supportive treatment. Mechanical ventilation was not required. The patient was transferred to the intensive care unit with a diagnosis of FES and she was discharged from the hospital with healing after twenty days. The patient's consent was obtained for this study.

\section{DISCUSSION}

Although the most common cause is an orthopedic trauma, such as a femur fracture, fat embolism may also stem from thoracic traumas, burns, soft-tissue injuries, non-traumatic causes (such as pancreatitis, diabetes, osteomyelitis and panniculitis), and cosmetic procedures, such as liposuction, lipoinjection, and fat grafting. ${ }^{[4,5]}$ In the literature, there are few cases reports describing fat embolism following buttock augmentation with different materials. ${ }^{[6]}$

There are two theories on the pathogenesis of fat embolism. According to the theory of mechanical obstruction, either fragment of fatty tissue cause obstruction in the pulmonary microvascular system or smaller-sized oil droplets and free fatty acids that pass from the pulmonary circulation to the systemic circulation affect other organs without causing any respiratory symptom. Fat embolism can be the result of a paradoxical embolism (the embolus passes from a patent foramen oval and enters the arterial circulation) or a microembolism (small emboli pass through the pulmonary artery
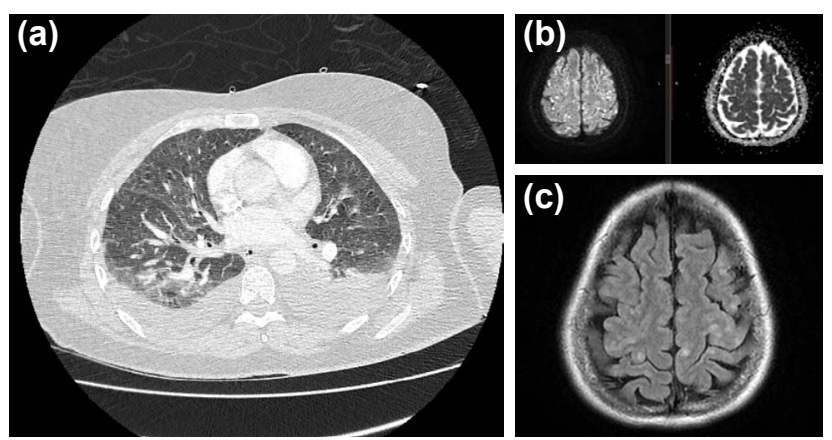

Figure 1. (a) Thorax computed tomography showed bilateral ground-glass opacities and pleural effusion. (b) Diffusion-weighted images $(b=1.000)$ show multiple millimetric foci of diffusion restriction and $A D C$ reduction in both cerebral hemispheres. (c) T2-weighted images demonstrate multiple millimetric hyperintense foci in both cerebral hemispheres. into the pulmonary circulation and then to the systemic circulation). According to the biochemical theory, free fatty acids composed of neutral triglycerides cause damage to the capillary endothelium and stimulate cell migration and chemical mediator release from neutrophils. Complement system activation, chylomicrons, and the toxins released from leukocytes further increase the damage. In addition, intravascular coagulation occurs due to the release of thromboplastin from tissue fat. ${ }^{[7-9]}$

Given its longer duration of effects, its biodegradability, and its biocompatibility, the use of HA has become widespread, especially for facial aesthetics in recent years. Mild or local complications are common after facial injection, but rarely some serious complications, such as skin necrosis, blindness, and cerebral infarction, may occur. ${ }^{[10-12]}$ Cases of cerebral infarction following periocular or perinasal HA injection have been reported. ${ }^{[13,14]}$

A review of 50 studies on buttock filler injections concluded that HA injection is effective but temporary and expensive. Of the 7834 patients who received buttock injections, only 69 patients had HA injections and nearly $40 \%$ of these experienced minor side effects, such as edema, itching, pain, and hematoma. ${ }^{[15-17]}$

In a study involving more than 4000 patients who underwent breast augmentation using HA fillers, no serious complications were reported except for some local side effects. ${ }^{[1]}$

Although given the absence of a gold standard diagnostic test or pathognomonic feature, several authors have proposed clinical diagnostic criteria (Gurd and Wilson's criteria, Modified Gurd's criteria, Schonfeld's criteria). ${ }^{[19,20]}$ According to these criteria, our patient is a rare case, diagnosed with fat embolism syndrome after gluteal augmentation with hyaluronic acid. She had no skin findings, but she was hypoxemic and lung computed tomography showed ground-glass densities and pleural effusion similar to CT features of FES. ${ }^{[2]}$ She had a disorder of consciousness with multiple cerebral white lesions on brain MRI. There are no definitive treatments for FES. Although the administration of systemic corticosteroids and heparin are controversial, we preferred to use them. ${ }^{[22]}$

The outcome of patients with FES is generally favorable. Pulmonary, neurological, and dermatologic manifestations of FES generally completely resolve. ${ }^{[3]}$ Our patient recovered without a squeal.

\section{Conclusion}

Patients presenting to the emergency department with altered mental status should be questioned for recent surgical or invasive aesthetic procedures. Fat embolism syndrome should be considered even if the patient has no petechial rash. The classic triad is not present in all patients. Although FES diagnosis is based on clinical features, imaging studies can 
help and speed up the diagnosis. Brain MRI, including diffusion-weighted sequences and lung $C T$, should be the imaging modality of choice in these patients.

Informed Consent: Written informed consent was obtained from the patient for the publication of the case report and the accompanying images.

Peer-review: Internally peer-reviewed.

Authorship Contributions: Concept: I.U.; Design: I.U., S.Y.; Supervision: I.U., S.Y.; Resource: I.U., M.E.; Materials: I.U., S.Y., M.E.; Data: I.U., S.Y., M.E.; Interpretation: I.U., S.Y., M.E.; Literature search: I.U., S.Y.; Writing: İ.U.; Critical revision: I.U.

\section{Conflict of Interest: None declared.}

Financial Disclosure: The authors declared that this study has received no financial support.

\section{REFERENCES}

1. Stein PD, Yaekoub AY, Matta F, Kleerekoper M. Fat embolism syndrome. Am J Med Sci 2008;336:472-7. [CrossRef]

2. Rothberg DL, Makarewich CA. Fat Embolism and Fat Embolism Syndrome. J Am Acad Orthop Surg 2019;27:e346-55. [CrossRef]

3. Scarpino M, Lanzo G, Lolli F, Grippo A. From the diagnosis to the therapeutic management: cerebral fat embolism, a clinical challenge. Int J Gen Med 2019;12:39-48. [CrossRef]

4. de Lima E Souza R, Apgaua BT, Milhomens JD, Albuquerque FT, Carneiro LA, Mendes MH, et al. Severe fat embolism in perioperative abdominal liposuction and fat grafting. Brazilian J Anesthesiology (Elsevier) 2016;66:324-8. [CrossRef]

5. Ross RM, Johnson GW. Fat embolism after liposuction. Chest 1988;93:1294-5. [CrossRef]

6. Mendoza-Morales RC, Camberos-Neva EV, Luna-Rosas A, Garces-Ramirez L, De la Cruz F, Garcia-Dolores F. A fatal case of systemic fat embolism resulting from gluteal injections of vitamin e for cosmetic enhancement. Forensic Science International 2015;259:e1-4. [CrossRef]

7. Hulman G. The pathogenesis of fat embolism. J Pathology 1995;176:3-9.

8. Pell AC, Hughes D, Keating J, Christie J, Busuttil A, Sutherland GR. Brief report: fulminating fat embolism syndrome caused by paradoxical embo- lism through a patent foramen ovale. N Engl J Med 1993;329:926-9.

9. Sulek CA, Davies LK, Enneking FK, Gearen PA, Lobato EB. Cerebral microembolism diagnosed by transcranial Doppler during total knee arthroplasty: correlation with transesophageal echocardiography. Anesthesiology 1999;91:672-6. [CrossRef]

10. Park TH, Seo SW, Kim JK, Chang CH. Clinical experience with hyaluronic acid-filler complications. J Plast Reconstr Aesthet Surg 2011;64:892-6. [CrossRef]

11. Kim DW, Yoon ES, Ji YH, Park SH, Lee BI, Dhong ES. Vascular complications of hyaluronic acid fillers and the role of hyaluronidase in management. J Plast Reconstr Aesthet Surg 2011;64:1590-5. [CrossRef]

12. Wang Q, Zhao Y, Li H, Li P, Wang J. Vascular Complications After Chin Augmentation Using Hyaluronic Acid. Aesthetic Plast Surg 2018;42:553-9. [CrossRef]

13. Ansari ZA, Choi CJ, Rong AJ, Erickson BP, Tse DT. Ocular and cerebral infarction from periocular filler injection. Orbit 2019;38:322-4. [CrossRef]

14. Kim EG, Eom TK, Kang SJ. Severe visual loss and cerebral infarction after injection of hyaluronic acid gel. J Craniofac Surg 2014;25:684-6.

15. Oranges CM, Tremp M, di Summa PG, Haug M, Kalbermatten DF, Harder Y, et al. Gluteal Augmentation Techniques: A Comprehensive Literature Review. Aesthet Surg J 2017;37:560-9. [CrossRef]

16. Camenisch CC, Tengvar M, Hedén P. Macrolane for volume restoration and contouring of the buttocks: magnetic resonance imaging study on localization and degradation. Plast Reconstr Surg 2013;132:522-9e.

17. De Meyere B, Mir-Mir S, Peñas J, Camenisch CC, Hedén P. Stabilized hyaluronic acid gel for volume restoration and contouring of the buttocks: 24-month efficacy and safety. Aesthetic Plast Surg 2014;38:404-12.

18. Ishii H, Sakata K. Complications and management of breast enhancement using hyaluronic acid. Plast Surg (Oakv) 2014;22:171-4. [CrossRef]

19. Gurd AR. Fat embolism: an aid to diagnosis. J Bone Joint Surg Br 1970;52:732-7. [CrossRef]

20. Schonfeld SA, Ploysongsang Y, DiLisio R, Crissman JD, Miller E, Hammerschmidt DE, et al. Fat embolism prophylaxis with corticosteroids. A prospective study in high-risk patients. Ann Intern Med 1983;99:43843. [CrossRef]

21. Newbigin K, Souza CA, Torres C, Marchiori E, Gupta A, Inacio J, et al. Fat embolism syndrome: State-of-the-art review focused on pulmonary imaging findings. Respir Med 2016;113:93-100. [CrossRef]

22. Weinhouse GL. Fat Embolism Sydrome. UpToDate (Online) 2019. Available from: https://www.uptodate.com/contents/fat-embolism-syndrome\#H2736501445. Accessed 05 December, 2019.

\section{OLGU SUNUMU - ÖZET}

\section{Hyalüronik asit ile kalça dolgusu sonrası yă̆ emboli sendromu olgusu \\ Dr. İlhan Uz, Dr. Sercan Yalçınlı, Dr. Mehmet Efe \\ Ege Üniversitesi Tıp Fakültesi, Acil Tıp Anabilim Dalı, Izmir}

Yağ embolisi sendromu, klasik olarak akut solunum yetmezliği, nörolojik anormallikler ve peteşiyal döküntü kombinasyonu ile ortaya çıkar. Kırk altı yaşında kadın hasta acil servise ajitasyon, bilinç değişikliği ve uykuya meyil şikayetleri ile başvurdu. Hastanın acil servise gelmeden saatlerce önce bir güzellik merkezinde, kalçalarına estetik amaçlı hyalüronik asit (HA) enjeksiyonu yapıldığı öğrenildi. Cilt bulguları yoktu ancak hipoksemi ile akciğer bilgisayarlı tomografisinde (BT) iki taraflı buzlu cam opasiteleri ve plevral efüzyon bulguları mevcuttu, ayrıca beyin manyetik rezonans görüntülerinde (MRG) çok sayıda beyaz lezyon vardı. Acil servise bilinçte ani değişiklikler ile başvuran hastalar, geçirilmiş cerrahi veya invaziv estetik prosedürler için sorgulanmalıdır. Yağ embolisi sendromu, hastanın peteşial döküntüleri olmasa bile düşünülmelidir. Beyin MR ve akciğer BT bu hastalarda tercih edilen görüntüleme yöntemi olmalıdır.

Anahtar sözcükler: Acil tıp; hyalüronik asit enjeksiyonu; yağ emboli sendromu. 